\title{
PENENTUAN WAKTU DAN METODE IMPLEMENTASI VOLTE PADA JARINGAN LTE (STUDI KASUS DI TELKOMSEL)
}

Enov Tikupasang ${ }^{1}$, Nurul Hiron ${ }^{2}$, Imam Taufiqurrahman ${ }^{3}$

Teknik Elektro, Universitas Siliwangi, Tasikmalaya, Indonesia ${ }^{1,2,3}$ email: enov.tikupasang@ui.ac.id ${ }^{1}$

\begin{abstract}
$4 G$ LTE technology is implemented to improve the quality and speed data services, corporate image, and interoperability with other operators. This study analyzes the VoLTE as an alternative voice services over LTE networks with limited frequency bandwidth, but the contribution of voice services is still high in the case study in Telkomsel. Use of VoLTE is the next stage after the voice CS fallback. The purpose of this research is to develop a model to assess the feasibility of implementation of VoLTE by the various scenarios timing and technology method in order to lower the risk value of the implementation of LTE, so it can determine the timing and the proper method for implementation of VoLTE service features on LTE network in two ways that are SRVCC system (Single Radio Voice Call Continuity) or directly on the PS handover system. The method used in this research are complementary or triangulation with scientific and natural, using statistikk regression, discrete random variables, bandwidth calculation, and business value. In addition, to calculate the risk value of probabilistic uncertainty, the use of sensitivity analysis and risk analysis with Monte Carlo simulation.The expected result is the optimization and efficient use of bandwidth as well as proving a hypothesis about the project feasibility study of the VoLTE services implementation.
\end{abstract}

Keywords: bandwidth, model, PS handover, SRVCC, VoLTE.

\begin{abstract}
Abstrak
Teknologi 4G LTE diimplementasikan untuk meningkatkan kualitas dan speed layanan data, image perusahaan, dan interoperability dengan operator lain. Penelitian ini menganalisis VoLTE sebagai alternatif layanan voice di atas jaringan LTE dengan keterbatasan bandwidth frekuensi, tetapi kontribusi layanan voice yang masih tinggi pada studi kasus di Telkomsel. Penggunaan VoLTE merupakan tahapan selanjutnya setelah voice CS fallback. Tujuan dari penelitian ini adalah membangun sebuah model untuk menilai kelayakan implementasi VoLTE dengan berbagai skenario waktu dan metode teknologi dalam rangka menurunkan nilai risiko dari implementasi LTE, sehingga dapat menentukan waktu dan metode yang tepat bagi implementasi fitur layanan VoLTE pada jaringan LTE dengan dua cara yaitu sistem SRVCC (Single Radio Voice Call Continuity) atau langsung pada sistem PS handover. Metoda penelitian yang digunakan adalah komplementer atau triangulation dengan ilmiah dan alamiah, dengan menggunakan statistik regresi, variabel acak berlainan, perhitungan bandwidth, dan nilai bisnis. Disamping itu untuk menghitung nilai risiko dari probabilistik ketidakpastian, maka digunakan analisis sensitivitas dan analisis risiko melalui simulasi Monte Carlo. Hasil yang diharapkan adalah optimalisasi dan efisiensi penggunaan bandwidth serta pembuktian hipotesis tentang studi kelayakan proyek implementasi layanan VoLTE.
\end{abstract}

Kata Kunci: bandwidth, model, PS handover, SRVCC, VoLTE.

\section{PENDAHULUAN}

Menurut Mishra, Frost, Sullivan [1], implementasi 4G LTE (Long Term Evolution) secara global cukup signifikan di Asia, yaitu 318 operator di 111 negara. Sebanyak 10 operator telah meluncurkan VoLTE (Voice over LTE) dan sebanyak 66 operator di 35 negara berinvestasi dalam penggunaan VoLTE. Tiga operator telekomunikasi utama di Korea (SK Telecom, KT, dan LG U+) meluncurkan VoLTE pada semester kedua 2012. Sejak peluncuran LTE dan VoLTE, ARPU dari ketiga operator telah tumbuh secara signifikan. Menurut Telecoms [2], SK Telecom Korea menggunakan LTE di 3 spektrum yang berbeda dengan masing-masing bandwidth $800 \mathrm{MHz}(10 \mathrm{MHz}), 1800 \mathrm{MHz}$ (20 MHz), dan $2100 \mathrm{MHz}(10 \mathrm{MHz})$. Sehingga total bandwidth yang digunakan secara agregasi oleh SK Telecom Korea sebesar $40 \mathrm{MHz}$ yang dapat menghasilkan throughput sebesar 300 Mbps. Sedangkan menurut Churchill [3] dan Parker [4], VoLTE dapat diimplementasikan di bandwidth 5 $\mathrm{MHz}$ pada operator MetroPCS di Amerika, ketika migrasi dari CDMA ke LTE.

Sementara itu di tahun 2014 Telkomsel (yang selanjutnya disebut perusahaan) dihadapkan pada tekanan untuk melakukan implementasi teknologi 4G LTE (Generasi keempat Long Term Evolution) dalam rangka meningkatkan image, corporate value dan meningkatkan kualitas layanan data serta untuk mengakomodir interoperability dengan operator luar negeri sebagai roaming partner dalam rangka mendukung inbound dan outbound roaming internasional.

Rencana implementasi LTE terbentur pada keterbatasan alokasi spektrum dan bandwidth frekuensi. Hal berbeda ketika teknologi 3G UMTS (Universal Mobile Telecommunication System) pertama kali diimplementasikan di tahun 2006. Saat itu terdapat alokasi spektrum di 2100 $\mathrm{MHz}$ dan bandwidth $15 \mathrm{MHz}$, dan juga dimanfaatkan untuk mendukung penambahan kapasitas layanan voice dan SMS di jaringan CS (circuit switch), dengan produktivitas seperti terlihat pada Tabel 1 . 
Tbl 1

\begin{tabular}{|c|c|c|c|c|c|}
\hline \multirow[t]{2}{*}{ Teknologi } & \multirow[t]{2}{*}{ Spektrum } & \multirow[t]{2}{*}{ Bandwidth } & Layanan & Layanan & \multirow[t]{2}{*}{ Expected QoS } \\
\hline & & & Legacy & Data & \\
\hline 2G GSM & $900 \mathrm{MHz}$ & $7,5 \mathrm{MHz}$ & Voice, SMS & GPRS/EDGE & $237 \mathrm{Kbps}-474 \mathrm{Kbps}$ \\
\hline 2G DCS & $1800 \mathrm{MHz}$ & $22.5 \mathrm{MHz}$ & Voice, SMS & GPRS/EDGE & $237 \mathrm{Kbps}-1.3 \mathrm{Mbps}$ \\
\hline 3G UMTS & $2100 \mathrm{MHz}$ & $15 \mathrm{MHz}$ & Voice, SMS & HSPA+/ DC-HSPA & $21-42$ Mbps \\
\hline \multicolumn{3}{|c|}{ Revenue (tahun 2013) } & $\mathrm{Rp} 48,7 \mathrm{~T}$ & Rp 11,3 T & \\
\hline \multicolumn{3}{|c|}{ Kontribusi terhadap Revenue (2013) } & $80 \%$ & $20 \%$ & \\
\hline
\end{tabular}

Teknologi 4G LTE tidak digunakan untuk layanan voice dan SMS, padahal layanan voice tetap diperlukan, sementara pada teknologi LTE digunakan hanya dapat memberi layanan data. Hal ini sangat berisiko bagi pendapatan dan pertumbuhan usaha perusahaan, apalagi jika LTE mengambil spektrum dan bandwidth yang ada saat ini, mengakibatkan adanya risiko menurunnya performansi layanan voice dan SMS.

Kontribusi layanan voice masih mendominasi pendapatan perusahaan lebih dari 58\% hingga tahun 2013. Sementara layanan data memberi kontribusi sebesar $20 \%$ dari total pendapatan dengan pertumbuhan $33 \%$ YoY.

Teknologi LTE 4G dapat diimplementasikan pada jaringan Telkomsel dengan melakukan upgrade dari perangkat RAN (Radio Access Network) yang saat ini digunakan dengan sistem single RAN dan perangkat core dengan sistem triple access reconfigurations. Topologi dasar teknologi LTE seperti ditunjukkan pada gambar 1.

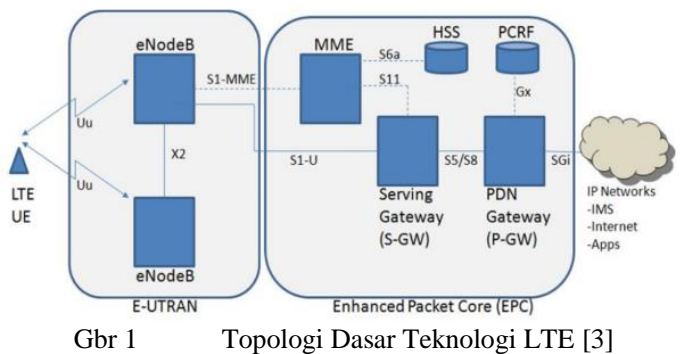

Saat 4G LTE diimplementasikan, layanan voice dapat diberikan dengan 2 pilihan. Pertama, tetap pada jaringan $3 \mathrm{G} / 2 \mathrm{G}$ concurrent sebagai prime, yang dilengkapi dengan fitur CS fallback. Kedua, menggunakan voice over LTE secara penuh. Jika VoLTE diterapkan secara penuh hal ini harus melalui beberapa tahapan seperti terlihat pada Gambar 2.

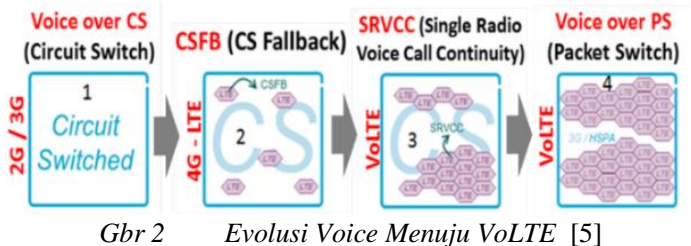

Dari sisi efisiensi bandwidth, layanan VoLTE akan menghemat resource bandwitdh. Perhitungan VoLTE menurut Elnashar [6], misalnya dengan menggunakan asumsi full rate 12,2 kbps speech code AMR (Adaftive Multi-Rate) yang digunakan setiap $20 \mathrm{~ms}$ dalam 1 cell, maka pada cell tersebut paket VoLTE dapat digunakan untuk 260 user. Dengan asumsi aktual setengah dari kapasitas maksimum yaitu 130 user dan dengan asumsi pada bandwidth $5 \mathrm{MHz}$ (maksimum seperti pada Tabel 2) menghasilkan throughput per cell $43 \mathrm{Mbps}$, maka throughput per user adalah $330 \mathrm{kbps}$ (43 Mbps/130 user), tetapi untuk perencanaan, biasanya menggunakan throughput $8 \mathrm{Mbps}$, sehingga throughput rata-rata tiap user adalah $61 \mathrm{kbps}(8$ Mbps/130 user).

Tbl 2 Spesifikasi Maksimum Throughput 4G LTE [7]

\begin{tabular}{ll}
\hline \multicolumn{3}{c}{ 4G LTE } \\
\hline Bandwidth & Throughput \\
\hline $\mathbf{3} \mathbf{M H z}$ & $25 \mathrm{Mbps}$ \\
\hline $\mathbf{5} \mathbf{M H z}$ & 43 Mbps \\
\hline $\mathbf{1 0} \mathbf{M H z}$ & $86 \mathrm{Mbps}$ \\
\hline $\mathbf{1 5} \mathbf{M H z}$ & $129 \mathrm{Mbps}$ \\
\hline $\mathbf{2 0} \mathbf{M H z}$ & $173 \mathrm{Mbps}$ \\
\hline $\mathbf{1 0 0} \mathbf{M H z}$ & $\sim 1 \mathrm{Gbps}$
\end{tabular}

\section{KAJIAN PUSTAKA}

A. Evolusi Telekomunikasi Wireless

1) Dari Generasi $1 G$ ke $3 G$

Cox menyatakan bahwa sistem telekomunikasi seluler pertama kali diperkenalkan pada awal 1980-an. Generasi pertama (1G) sistem yang menggunakan teknik komunikasi analog, yang mirip dengan yang digunakan oleh radio analog tradisional. Sel-sel individual yang besar dan sistem tidak menggunakan spektrum radio yang tersedia secara efisien, sehingga kemampuan mereka dengan standar saat ini sangat kecil. Perangkat mobile yang besar dan mahal dan dipasarkan hampir secara eksklusif pada pengguna bisnis.

Telekomunikasi seluler mengeluarkan produk konsumen dengan pengenalan sistem generasi kedua (2G) pada awal 1990-an. Sistem ini yang pertama kali menggunakan teknologi digital, yang memungkinkan penggunaan spektrum radio yang lebih efisien dan pengenalan perangkat yang lebih kecil dan murah. Awalnya sistem ini dirancang hanya untuk suara (voice), namun kemudian ditingkatkan untuk mendukung pesan instan melalui layanan Short Message Service (SMS). Sistem 2G yang paling populer adalah Global System for Mobile Communications (GSM), yang awalnya dirancang sebagai teknologi pan-Eropa, tetapi yang kemudian menjadi populer di seluruh dunia. Selain itu sistem $2 \mathrm{G}$ yang terkenal adalah IS-95, atau dikenal sebagai cdmaOne, yang dirancang oleh Qualcomm, dan yang menjadi sistem $2 \mathrm{G}$ yang dominan di Amerika Serikat.

Keberhasilan sistem komunikasi $2 \mathrm{G}$ datang pada saat yang sama dengan awal perkembangan internet. Sehingga hal tersebut wajar bagi operator jaringan untuk membawa dua konsep bersama-sama, dengan 
memungkinkan pengguna untuk melakukan download data ke perangkat mobile. Untuk melakukan hal ini, yang disebut sistem $2.5 \mathrm{G}$ dibangun di atas ide-ide asli dari $2 \mathrm{G}$, dengan memperkenalkan paket jaringan inti yang beralih domain dan dengan memodifikasi air interface, sehingga bisa menangani data serta suara (voice). The General Packet Radio Service (GPRS) dimasukkan ke dalam teknik sistem GSM, sedangkan IS-95 dikembangkan menjadi sistem yang dikenal sebagai IS-95B.

Pada saat yang sama, tingkat data yang tersedia melalui internet yang semakin meningkat. Hal ini membuat desainer meningkatkan kinerja sistem 2G dengan menggunakan teknik Enhanced Data Rates for GSM Evolution (EDGE) dan kemudian diperkenalkan sistem generasi ketiga (3G) yang lebih handal (powerful) pada tahun-tahun setelah tahun 2000. Sistem 3G menggunakan Teknik yang berbeda untuk transmisi dan penerimaan radio dari pendahulu $2 \mathrm{G}$, dimana sistem $3 \mathrm{G}$ ini dapat meningkatkan kecepatan data puncak (peak data rates) yang ditanganinya, dan yang menggunakan spektrum radio yang tersedia masih lebih efisien dari penggunaannya.

2) Sistem Generasi Ketiga

Selanjutnya Cox menyatakan bahwa sistem 3G yang dominan di dunia adalah UMTS. UMTS dikembangkan dari GSM dengan sepenuhnya mengubah teknologi yang digunakan pada interface udara, sekaligus menjaga jaringan inti hampir tidak berubah. Sistem ini kemudian ditingkatkan untuk aplikasi data, dengan memperkenalkan teknologi 3.5G HSDPA (High Speed Downlink Packet Access) dan HSUPA (High Speed Uplink Packet Access), yang secara kolektif disebut HSPA (High Speed Packet Access).

B. Kebutuhan Gerenasi Keempat LTE

Teknologi LTE dibutuhkan dengan beberapa alasan diantaranya adalah downlink peak data rate dapat mencapai $100 \mathrm{Mbps}$ dan uplink peak data rate sampai $50 \mathrm{Mbps}$ pada bandwidth $20 \mathrm{MHz}$, beroperasi pada dua mode TDD dan FDD, skalabilitas bandwidth sampai $20 \mathrm{MHz}$, dapat meningkatkan spectral efficiency lebih baik dari release 6 HSPA dengan faktor 2 sampai 4, mengurangi latency sampai menjadi $10 \mathrm{msec}$ (waktu pulang pergi antara handphone pengguna dan base station), dan kurang dari $100 \mathrm{msec}$ transisi dari tidak aktif menjadi aktif, dan serta kelebihan lainnya.

C. Evolusi Layanan Voice

Awalnya teknologi telekomunikasi wireless digital 2G GSM hanya

digunakan untuk layanan panggilan suara (voice call) dan kemudian dikembangkan untuk layanan SMS (pesat singkat), Pada teknogi 2G ini kemudian dikembangkan untuk layanan data (broadband) dengan teknologi GPRS (General Packet Radio Service) dan EDGE (Enhanced Data Rates for GSM Evolution). Pada gerersi 3G UMTS (Universal Mobile Telecommunication System), layanan voice tetap digunakan pada jaringan CS (Circuit Switch). Barulah pada generasi 4G LTE (Long Term Evolution) yang berbasis IP (Internet Protocol), layanan voice tidak ada lagi, sehingga penggunaan layanan voice akan handover ke $3 \mathrm{G} / 2 \mathrm{G}$ circuit switch melalui sistem CSFB (CS fallback).

\section{METODE}

\section{A. Metodologi dan pemodelan}

Untuk membangun model yang akan digunakan pada penelitian ini, maka hal yang pertama dilakukan adalah mengumpulkan data-data trend trafik dan revenue perusahaan baik untuk layanan voice, SMS dan data, sedangkan biaya operasional $2 \mathrm{G}$ dan $3 \mathrm{G}$ diasumsikan tetap dan biaya yang terkait investasi (CAPEX) serta biaya operasional (OPEX) untuk melakukan implementasi layanan LTE pada tahun 2015 dan VoLTE pada waktu dan metode yang tepat di wilayah Jabotabek, sehingga kelayakan bisnis perusahaan dapat diperhitungkan. Pada pemodelan ini diasumsikan ekosistem handset mendukung untuk dilakukan implementasi layanan LTE maupun VoLTE. Untuk menggambarkan parameter dan variabel yang digunakan, maka dapat menggunakan proses pemodelan bisnis dari Meredith, Shafer, dan Turban [8] sebagai berikut:

1) Identifikasi masalah atau peluang.

2) Pembentukan model.

3) Pengumpulan data trafik, revenue, dan biaya ataupun estimasinya.

4) Analisis model berikut validasinya.

5) Penentuan waktu (timing) dan metode teknologi yang tepat untuk implementasi dan manajemen proyek LTE dan VoLTE.

Proses pemodelan tersebut ditunjukkan pada Gambar 3.

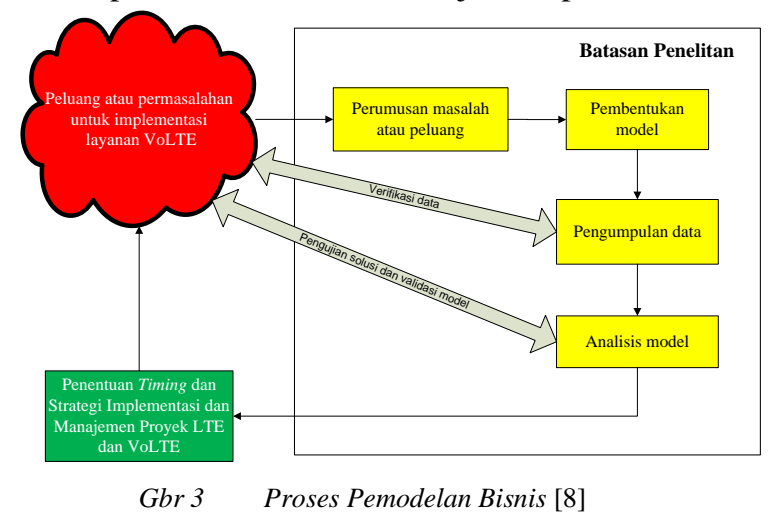

Meredith, Shafer, dan Turban [8] menjelaskan bahwa pada keadaan bisnis yang nyata, peluang dan permasalahan yang dihadapi kadang tidak terlihat dengan jelas. Dengan mengamati fakta dan trend yang terjadi di industri telekomunikasi saat ini, maka identifikasi permasalahan atau peluang menjadi hal yang sangat penting dan merupakan hal yang krusial pada awal proses penelitian, terutama dalam hal memprediksi peluang dan risiko implementasi fitur layanan VoLTE.

\section{B. Sekenario dan Data Amatan}

Data yang digunakan pada penelitian ini adalah data primer dan sekunder dari estimasi metode perencanaan dan quality network dan data annual report Telkomsel yang telah di-published. Data yang dibutuhkan adalah estimasi trafik dan revenue per site di masing-masing layanan (voice, SMS dan data) serta di masing-masing spektrum (2G $900 \mathrm{MHz}$, 2G $1800 \mathrm{MHz}$, dan 3G 2100). Data ini akan digunakan untuk pembuatan model implementasi teknologi 4G LTE untuk kemungkinan di spektrum $900 \mathrm{MHz}, 1800 \mathrm{MHz}$ dan 2100 MHz. Pada tabel 3 adalah data estimasi dari trafik layanan voice, SMS dan layanan data pada tahun 2014 dan 2015. 
Tbl 3 Data Estimasi Trafik Layanan Telkomsel Jakarta 2014-2015 [9]

\begin{tabular}{|c|c|c|c|c|c|}
\hline Tahun & Periode & Bulan & $\begin{array}{l}\text { Estimasi Trafik } \\
\text { Voice (Erlang) }\end{array}$ & $\begin{array}{c}\text { Estimasi Trafik SMS } \\
\text { (Unit) }\end{array}$ & $\begin{array}{c}\text { Estimasi Trafik Data } \\
\text { (Tera Bytes) }\end{array}$ \\
\hline \multirow[t]{12}{*}{2014} & 1 & Januari & $72,000,000$ & $1,900,000,000$ & 3,700 \\
\hline & 2 & Februari & $67,000,000$ & $1,800,000,000$ & 3,500 \\
\hline & 3 & Maret & $74,000,000$ & $1,800,000,000$ & 4,100 \\
\hline & 4 & April & $73,000,000$ & $1,300,000,000$ & 4,000 \\
\hline & 5 & Mei & $77,000,000$ & $1,700,000,000$ & 4,300 \\
\hline & 6 & Juni & $76,000,000$ & $1,900,000,000$ & 4,300 \\
\hline & 7 & Juli & $70,000,000$ & $1,800,000,000$ & 4,700 \\
\hline & 8 & Agustus & $73,000,000$ & $1,700,000,000$ & 4,800 \\
\hline & 9 & September & $79,000,000$ & $1,800,000,000$ & 5,000 \\
\hline & 10 & Oktober & $81,000,000$ & $1,800,000,000$ & 5,600 \\
\hline & 11 & November & $80,000,000$ & $1,700,000,000$ & 5,800 \\
\hline & 12 & Desember & $82,000,000$ & $1,800,000,000$ & 6,300 \\
\hline 2014 & & & $904,000,000$ & $21,000,000,000$ & 56,100 \\
\hline \multirow[t]{3}{*}{2015} & 1 & Januari & $79,000,000$ & $1,700,000,000$ & 6,400 \\
\hline & 2 & Februari & $74,000,000$ & $1,600,000,000$ & 6,000 \\
\hline & 3 & Maret & $84,000,000$ & $1,700,000,000$ & 7,100 \\
\hline Total & & & $2,045,000,000$ & $47,000,000,000$ & 131,700 \\
\hline
\end{tabular}

Selanjutnya dengan menghitung persentasi jumlah BTS dapat ditentukan estimasi jumlah BTS dan NodeB di Jakarta, dan NodeB di Jakarta terhadap jumlah secara nasional, maka seperti pada tabel 4.

Tbl 4 Estimasi Jumlah BTS/NodeB Telkomsel Jabotabek Per Spektrum

Estimasi Jumlah BTS Jabotabek Per Teknologi

\begin{tabular}{|c|c|c|c|c|c|c|c|c|c|}
\hline \multirow[t]{2}{*}{ Tahun } & \multicolumn{4}{|c|}{ 2G GSM } & \multicolumn{2}{|c|}{$3 G$} & \multirow{2}{*}{$\begin{array}{l}\text { Total } \\
\text { BTS } \\
\text { Jabo }\end{array}$} & \multirow{2}{*}{$\begin{array}{l}(\%) \\
\text { BTS } \\
\text { Jabo }\end{array}$} & \multirow{2}{*}{$\begin{array}{c}\text { Total } \\
\text { BTS } \\
\text { Nasional }\end{array}$} \\
\hline & $\begin{array}{c}900 \\
\text { MHz }\end{array}$ & Porsi & $\begin{array}{c}1800 \\
\mathrm{MHz}\end{array}$ & Porsi & $\begin{array}{l}2100 \\
\mathrm{MHz}\end{array}$ & Porsi & & & \\
\hline 2006 & 977 & $36 \%$ & 1.108 & $41 \%$ & 604 & $22 \%$ & 2.689 & $17 \%$ & 16.057 \\
\hline 2007 & 1.190 & $34 \%$ & 1.435 & $41 \%$ & 686 & $25 \%$ & 3.493 & $17 \%$ & 20.858 \\
\hline 2008 & 1.500 & $33 \%$ & 1.765 & $39 \%$ & 1.235 & $27 \%$ & 4.500 & $17 \%$ & 26.872 \\
\hline 2009 & 1.677 & $32 \%$ & 2.003 & $39 \%$ & 1.510 & $29 \%$ & 5.190 & $17 \%$ & 30.992 \\
\hline 2010 & 2.113 & $31 \%$ & 2.532 & $38 \%$ & 2.079 & $31 \%$ & 6.724 & $18 \%$ & 36.557 \\
\hline 2011 & 2.343 & $31 \%$ & 2.847 & $37 \%$ & 2.414 & $32 \%$ & 7.604 & $18 \%$ & 42.623 \\
\hline 2012 & 2.562 & $27 \%$ & 3.262 & $34 \%$ & 3.650 & $39 \%$ & 9.474 & $17 \%$ & 54.297 \\
\hline 2013 & 2.745 & $24 \%$ & 3.547 & $31 \%$ & 5.011 & $44 \%$ & 11.303 & $16 \%$ & 69.864 \\
\hline 2014 & 2.738 & $22 \%$ & 3.596 & $29 \%$ & 6.100 & $49 \%$ & 12.434 & $15 \%$ & 85.420 \\
\hline
\end{tabular}

Selain data estimasi trafik, maka data estimasi revenue adalah data yang diperlukan untuk membuat model untuk implementasi LTE maupun VoLTE. Data estimasi revenue ini terdiri dari estimasi revenue layanan voice, SMS maupun layanan data (broadband service) seperti yang dinyatakan pada tabel 5. 
Tbl 5 Estimasi Revenue Antar Layanan Voice, SMS, Data Pada Telkomsel Jakarta

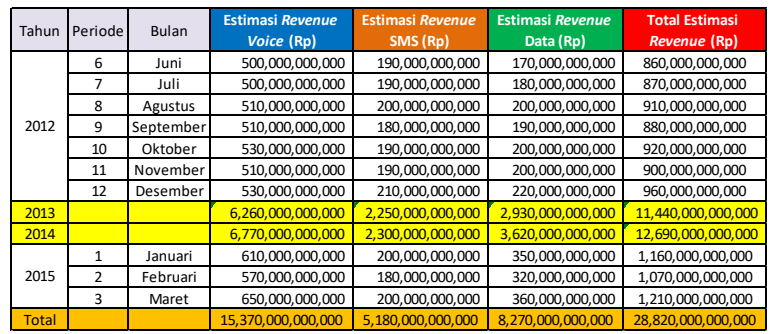

Dengan menggunakan data pada tabel 5 mengenai estimasi revenue pada masing-masing layanan di Telkomsel Jakarta, maka dapat dilakukan kalkulasi perbandingan rata-rata revenue dari layanan voice, SMS dan layanan data yang mengindikasikan kontribusi dari tiap layanan tersebut terhadap total revenue, seperti terlihat pada tabel 6 . Hal ini penting untuk melihat potensi layanan dan terlihat walaupun layanan voice sudah menjadi legacy service, tetapi masih memberikan kontribusi yang terbesar dari total revenue.

Tbl $6 \quad$ Kontribusi Revenue Layanan Voice, SMS, dan Data Telkomsel Jabotabek Pada Periode Juni 2012 - Maret 2015

\begin{tabular}{ccc}
\hline \multicolumn{3}{c}{$\begin{array}{c}\text { Rata-rata Kontribusi Revenue } \\
\text { Layanan dari Total }\end{array}$ Revenue } \\
\hline Voice & SMS & Data \\
\hline $\mathbf{5 3 . 3 3 \%}$ & $17.97 \%$ & $28.70 \%$ \\
\hline
\end{tabular}

Berdasarkan estimasi data revenue pada tiap layanan voice, SMS dan layanan data, maka dapat dibuatkan total revenue per tahun per layanan. Estimasi data revenue yang sudah lengkap selama 12 bulan adalah tahun 2013 dan 2014. Selanjutnya untuk tahun yang belum lengkap estimasi datanya dapat diasumsikan berdasarkan pertumbuhan (growth) pada laporan tahunan (annual report). Sehingga didapatkan hasil seperti pada tabel 7.

Tbl $7 \quad$ Estimasi Revenue per Tahun per Layanan di Jakarta 20062014 [10] [9]

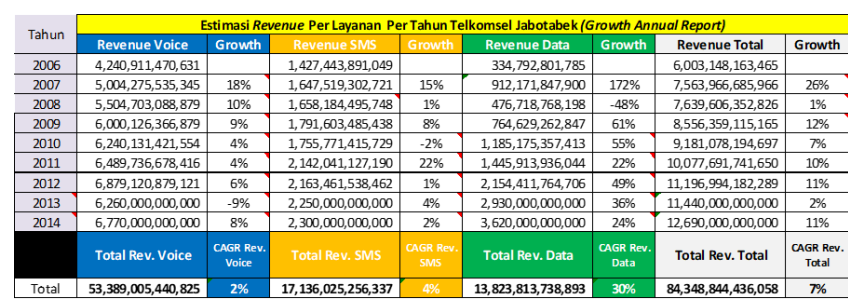

Estimasi trafik layanan voice 2014 nantinya akan dikonversi ke trafik payload layanan VoLTE dan dibandingkan dengan trafik voice CS untuk konsumsi bandwidth dan biaya frekuensi yang digunakan. Sedangkan estimasi nilai revenue dari tahun 2006 sampai 2014 akan digunakan untuk menentukan spot area layanan data LTE yang hasilnya dari tesis Wildan (2015) [11]. Sedangkan estimasi nilai revenue, jumlah eNodeB, dan estimasi trafik layanan data LTE dari bulan Desember 2014 sampai April 2005 dilakukan regresi dengan menggunakan aplikasi SPSS, sehingga diperoleh hasil regresi selama satu tahun untuk tahun 2015 seperti ditunjukkan pada tabel 8. Estimasi nilai revenue, jumlah eNodeB dan estimasi trafik payload di Telomsel Jakarta ini selanjutnya akan di analisis dengan menggunakan evaluasi proyek variabel acak berlainan (discrete random variable analysis), untuk mengetahui probabilitas nilai bisnis dan investasi menghadapi ketidakpastian sampai tahun 2019 yang merupakan estimasi masa lifetime dari investasi yang diimplementasikan.

Tbl 8 Tabel Hasil Regresi Linier Estimasi Revenue, eNodeB, dan Estimasi Trafik Payload Telkomsel Jakarta Tahun 2015

\begin{tabular}{|c|c|c|c|c|}
\hline Periode & Bulan & $\begin{array}{c}\text { Estimasi Revenue } \\
(\mathbf{R p})\end{array}$ & Jumlah eNodeB & $\begin{array}{c}\text { Estimasi Trafik (Payload, } \\
\text { Tbyte) }\end{array}$ \\
\hline
\end{tabular}

\begin{tabular}{ccrcc}
\hline $\mathbf{0}$ & Dec 2014 & $100,000,000$ & 110 & 3 \\
\hline $\mathbf{1}$ & Jan & $300,000,000$ & 143 & 6 \\
\hline $\mathbf{2}$ & Feb & $600,000,000$ & 143 & 15 \\
\hline $\mathbf{3}$ & Mar & $1,400,000,000$ & 180 & 30 \\
\hline $\mathbf{5}$ & Apr 2015 & $2,300,000,000$ & 180 & 60 \\
\hline $\mathbf{6}$ & May & $2,590,000,000$ & 204 & 64 \\
\hline $\mathbf{7}$ & Jun & $3,140,000,000$ & 222 & 78 \\
\hline $\mathbf{8}$ & Jul & $3,690,000,000$ & 240 & 92 \\
\hline $\mathbf{9}$ & Aug & $4,240,000,000$ & 257 & 106 \\
\hline $\mathbf{1 0}$ & Sep & $4,790,000,000$ & 275 & 119 \\
\hline $\mathbf{1 1}$ & Oct & $5,340,000,000$ & 293 & 133 \\
\hline $\mathbf{1 2}$ & Nov & $5,890,000,000$ & 311 & 147 \\
\hline Tahun $\mathbf{2 0 1 5} 2015$ & $6,440,000,000$ & 328 & 161 \\
\hline
\end{tabular}




\section{HASIL DAN PEMBAHASAN}

\section{A. Hasil Pengolahan dan Analisis}

Untuk merencanakan dan melakukan analisis terhadap pembangunan model yang akan dibuat tersebut, maka sebelumnya dibuat suatu framework model implementasi VoLTE seperti pada gambar 4, yang terdiri dari parameter dan variabel yang digunakan, struktur teori dan aplikasi yang digunakan, proses yang terjadi, hasil diperoleh, dan implikasinya yang terjadi.

Gbr 4. Framework Model Implementasi VoLTE

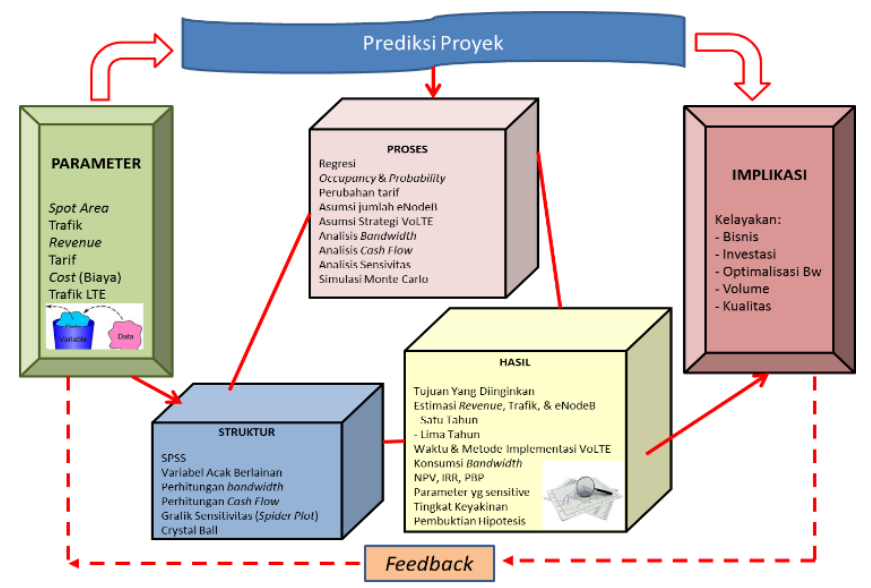

Untuk menghitung konsumsi bandwidth voice erlang, maka terlebih dahulu dilakukan konversi ke trafik per sektor, selanjutnya dengan menggunakan tabel B erlang, dapat diketahui jumlah carrier per TRX per sektor. Karena 1 channel carrier/TRX per site memerlukan $200 \mathrm{KHz}$, maka dapat diketahui bahwa trafik voice CS Telkomsel Jakarta tahun 2014 sebesar 904 juta erlang memerlukan bandwidth sebesar 4,35 MHz seperti pada tabel 9.

Tbl 9 Konsumsi Bandwidth Layanan Voice per Spektrum

\begin{tabular}{|c|c|c|c|c|c|c|c|c|c|c|c|c|c|c|}
\hline \begin{tabular}{|c} 
Kalkulasi \\
Per \\
Tahun
\end{tabular} & Spektrum & \begin{tabular}{|c|} 
Occ. Traffic \\
Voice \\
Tahun 2014
\end{tabular} & BW & $\%$ BW & $\begin{array}{c}\text { Traffic per } \\
\text { Technology } 2014\end{array}$ & $\begin{array}{c}\text { Rata" Trafik } \\
\text { per Hari }\end{array}$ & $\begin{array}{c}\text { Number } \\
\text { of BTS }\end{array}$ & \begin{tabular}{|c|} 
Traffic \\
per Site \\
per Day
\end{tabular} & $\begin{array}{l}\text { Traffic per } \\
\text { Sector per } \\
\text { day }\end{array}$ & \begin{tabular}{|c} 
Tch per Sector \\
(See Erlang \\
Table B)
\end{tabular} & $\begin{array}{c}\text { Carrier/T } \\
\text { Rx per } \\
\text { Sector }\end{array}$ & $\begin{array}{c}\text { Carrier/TRx } \\
\text { per Site }\end{array}$ & $\begin{array}{c}\text { BW of Radio } \\
\text { Channel (kHz) }\end{array}$ & $\begin{array}{c}\text { BW } \\
\text { Allocation } \\
\text { (MHz) }\end{array}$ \\
\hline \multirow{3}{*}{2014} & $2 \mathrm{G} 900 \mathrm{MHz}$ & \multirow{3}{*}{$904,000,000$} & 7.5 & $17 \%$ & $150,666,667$ & 412,785 & 2,738 & 151 & 50.3 & 58 & 7 & 22 & 200 & 4.35 \\
\hline & $2 \mathrm{G} 1800 \mathrm{MHz}$ & & 22.5 & $50 \%$ & $452,000,000$ & $1,238,356$ & 3,596 & 344 & 114.8 & 125 & 16 & 47 & 200 & 9.375 \\
\hline & $3 \mathrm{G} 2100 \mathrm{MHz}$ & & 15 & $33 \%$ & $301,333,333$ & 825,571 & 6,100 & 135 & 45.1 & 52 & 7 & 20 & 200 & 3.9 \\
\hline
\end{tabular}

Sedangkan dari tabel 3 diketahui estimasi trafik payload layanan data Telkomsel Jakarta tahun 2014 adalah 56.100 Terabyte, sedangkan tabel 8, diketahui estimasi trafik payload layanan data LTE sebesar 1.014 Terabyte. Selanjutnya dengan menggunakan data jumlah BTS pada tabel 4, maka dapat diperoleh rata-rata occupancy per BTS per hari seperti pada tabel 10 .

Tbl 10 Trafik Payload per Spektrum Frekuensi

\begin{tabular}{|c|c|c|c|c|c|c|c|c|}
\hline \multirow{2}{*}{$\begin{array}{c}\text { Kalkulasi } \\
\text { Per Tahun }\end{array}$} & Spektrum & Payload (TB) & BW & \% BW & $\begin{array}{c}\text { Payload per } \\
\text { Technology } \\
\text { (TB) per } \\
\text { Tahun }\end{array}$ & $\begin{array}{c}\text { Rata" } \\
\text { Payload per } \\
\text { Hari (TB) }\end{array}$ & $\begin{array}{c}\text { Number } \\
\text { of BTS }\end{array}$ & $\begin{array}{c}\text { Rata" Occ } \\
\text { Payload per } \\
\text { BTS per Hari } \\
\text { (GB) }\end{array}$ \\
\hline \multirow{2}{*}{2014} & $\mathbf{2 G ~ 9 0 0 ~ M H z}$ & \multirow{2}{*}{56,100} & 7.5 & $17 \%$ & 9,537 & 26 & 2,738 & 9.77 \\
\cline { 2 - 7 } & $\mathbf{2 G ~ 1 8 0 0 ~ M H z}$ & 22.5 & $50 \%$ & 28,050 & 77 & 3,596 & 21.88 \\
\cline { 2 - 6 } & $\mathbf{3 G} \mathbf{2 1 0 0 ~ M H z}$ & & 15 & $33 \%$ & 18,700 & 51 & 6,100 & 8.60 \\
\hline 2015 & LTE 900 MHz & 1,014 & 5 & & 1,014 & 2.78 & 328 & 8.68 \\
\hline
\end{tabular}

Untuk menghitung konsumsi bandwidth pada layanan data $2 \mathrm{G} / 3 \mathrm{G}$, maka sesuai dengan metode perhitungan oleh Elnashar [6], maka diperoleh konstanta seperti pada tabel 11, sesuai dengan bandwidth dan estimasi throughput yang diharapkan untuk perencanaan.

Tbl 11 Estimasi Perhitungan Throughput Untuk Perencanaan LTE [6]

\begin{tabular}{ccc}
\hline $\begin{array}{c}\text { Bandwidth } \\
\text { (MHz) }\end{array}$ & $\begin{array}{c}\text { Cell Average } \\
\text { Throughput } \\
\text { (Mbps) }\end{array}$ & $\begin{array}{c}\text { Konstanta } \\
\text { (MHz/Mbps) }\end{array}$ \\
\hline $\mathbf{5}$ & 8 & 0.6 \\
\hline $\mathbf{1 0}$ & 17 & 0.6 \\
\hline $\mathbf{1 5}$ & 25 & 0.6 \\
\hline $\mathbf{2 0}$ & 33 & 0.6 \\
\hline
\end{tabular}

Sehingga untuk perhitungan konsumsi bandwidth layanan data $2 \mathrm{G} / 3 \mathrm{G}$ menggunakan formula sebagai berikut : Konsumsi bandwidth $=$ DL throughput/sector $\mathrm{x}$ konstanta $\mathrm{x}$ 3 sector.

Sedangkan untuk menghitung konsumsi bandwidth pada layanan data LTE menggunakan perhitungan RB (Resource Block) seperti pada tabel 12.

Tbl 12 Perhitungan Resource Block Untuk Teknologi 4G LTE [6]

\begin{tabular}{|c|c|c|c|c|}
\hline \multicolumn{4}{|c|}{ Resource Block (RB) } & \multirow{2}{*}{$\begin{array}{r}\text { Satuan } \\
\text { Subcarrier }\end{array}$} \\
\hline $1 \mathrm{RB}$ & $=$ & 12 & & \\
\hline 1 RB & $=$ & 1 Subframe & $=2$ & Slot per milisecond \\
\hline 1 RB & $=$ & 7 & & Symbol OFDM \\
\hline $1 \mathrm{RB}$ & $=$ & 180 & & $\mathrm{kHz}$ \\
\hline \multicolumn{5}{|c|}{ Sehingga, } \\
\hline $1 \mathrm{RB}$ & $=$ & 84 & & Resource Element \\
\hline 1 RB & $=$ & 168 & & $\begin{array}{l}\text { Symbol } \\
\text { milisecond }\end{array}$ \\
\hline
\end{tabular}

Sehingga untuk perhitungan konsumsi bandwidth layanan data 4G LTE menggunakan konversi ke symbol per millisecond dan perhitungan RB (resource block). Jumlah bit yang digunakan tergantung kode modulasi yang digunakan misalnya untuk kode modulasi QPSK dengan 2 bit, 16 QAM dengan 4 bit, dan 64QAM dengan 8 bit. Untuk 1 RB (Resource Block) didefinisikan sama dengan 168 spms 
(symbol per millisecond) dan $1 \mathrm{RB}=64 \mathrm{RM}$ (Resource Element), sehingga konsumsi bandwidth menggunakan formula sebagai berikut :

Konsumsi bandwidth LTE $=$ Jumlah RB $\times 180$ $\mathrm{KHz} . . . \ldots \ldots \ldots \ldots \ldots \ldots \ldots \ldots \ldots(2)$
Sehingga dari hasil perhitungan konsumsi bandwidth layanan data $2 \mathrm{G} / 3 \mathrm{G}$ dan $4 \mathrm{G}$ LTE seperti ditunjukkan pada tabel 13.

Tbl 13

\begin{tabular}{|c|c|c|c|c|c|c|c|c|c|}
\hline Tahun & Spektrum & $\begin{array}{l}\text { Payload per } \\
\text { BTS (Gbyte) }\end{array}$ & $\begin{array}{c}\text { Payload per } \\
\text { Sector (Gbyte) }\end{array}$ & $\begin{array}{c}\text { Actual DL } \\
\text { Speed/Sector } \\
\text { (Mbps) }\end{array}$ & \begin{tabular}{c|} 
Daya \\
Tampung/ \\
Cell \\
\end{tabular} & \begin{tabular}{|c|} 
DL Average \\
Throughput/ \\
Sector (Mbps) \\
\end{tabular} & $\begin{array}{c}\text { BW } \\
\text { Consumption } \\
(\mathrm{MHz})\end{array}$ & & \\
\hline \multirow{3}{*}{2014} & $900 \mathrm{MHz}$ & 9.77 & 0.651 & 1.482 & $70 \%$ & 2.118 & 3.812 & & \\
\hline & $1800 \mathrm{MHz}$ & 21.88 & 1.459 & 3.320 & $70 \%$ & 4.743 & 8.537 & & \\
\hline & $2100 \mathrm{MHz}$ & 8.60 & 0.573 & 1.305 & $70 \%$ & 1.864 & 3.355 & & \\
\hline Tahun & Spektrum & $\begin{array}{l}\text { Payload per } \\
\text { BTS (Gbyte) }\end{array}$ & $\begin{array}{c}\text { Payload per } \\
\text { Sector (Gbyte) }\end{array}$ & $\begin{array}{c}\text { Actual DL } \\
\text { Speed/Sector } \\
\text { (Mbps) }\end{array}$ & \begin{tabular}{c|} 
Daya \\
Tampung/ \\
Cell \\
\end{tabular} & \begin{tabular}{|c|} 
DL Average \\
Throughput/Se \\
ctor (Mbps) \\
\end{tabular} & $\begin{array}{c}\text { Symbol/ms } \\
\text { (spms) }\end{array}$ & $\begin{array}{c}\text { Resource } \\
\text { Blocks (RB) }\end{array}$ & $\begin{array}{c}\text { BW } \\
\begin{array}{c}\text { Consumption } \\
(\mathrm{MHz})\end{array} \\
\end{array}$ \\
\hline 2015 & LTE $900 \mathrm{MHZ}$ & 8.68 & 0.578 & 1.316 & $70 \%$ & 1.880 & 235 & 1 & 0.252 \\
\hline
\end{tabular}

Sedangkan untuk perhitungan konsumsi bandwidth trafik layanan VoLTE yaitu dengan mengkonversi estimasi trafik voice CS tahun 2014 menjadi trafik payload VoLTE. Berdasarkan contoh kalkulasi dari Cisco dengan menggunakan codec \& bit rate (Kbps) G.729 call (8 Kbps codec bit rate), maka berdasarkan perhitungan seperti pada

\begin{tabular}{|c|c|c|c|c|c|c|c|c|c|}
\hline $\begin{array}{c}\text { Kalkulasi } \\
\text { VolTE Per } \\
\text { Tahun }\end{array}$ & Spektrum & $\begin{array}{c}\text { Throughput } \\
\text { (Mbps) }\end{array}$ & BW & \% BW & $\begin{array}{c}\text { Throughput } \\
\text { per } \\
\text { Technology } \\
\text { (Mbps) 2014 }\end{array}$ & $\begin{array}{c}\text { Rata" } \\
\text { Throughput } \\
\text { per Hari } \\
\text { (Mbps) }\end{array}$ & $\begin{array}{c}\text { Number } \\
\text { of BTS }\end{array}$ & $\begin{array}{c}\text { Rata" Occ } \\
\text { Throughtput } \\
\text { per BTS per } \\
\text { Hari (Mbps) }\end{array}$ & $\begin{array}{c}\text { Payload } \\
\text { (GByte) per } \\
\text { BTS }\end{array}$ \\
\hline \multirow{2}{*}{2014} & $2 \mathrm{G} 900 \mathrm{MHz}$ & \multirow{2}{*}{$151,872,000$} & 7.5 & $17 \%$ & $25,312,000$ & 69,348 & 2,738 & 25.33 & 11.13 \\
\cline { 2 - 9 } & $2 \mathrm{G} 1800 \mathrm{MHz}$ & $50 \%$ & $75,936,000$ & 208,044 & 3,596 & 57.85 & 25.42 \\
\cline { 2 - 9 } & $3 \mathrm{G} 2100 \mathrm{MHz}$ & & 15 & $33 \%$ & $50,624,000$ & 138,696 & 6,100 & 22.74 & 9.99 \\
\hline
\end{tabular}

lampiran 3 menurut Cisco [12], throughput per call $=11,2$ Kbps.

Berdasarkan tabel 3.2 bahwa estimasi trafik erlang voice Jakarta pada tahun 2014 adalah 904.000.000 erlang. Dengan menggunakan formula trafik erlang sebagai berikut:
Jumlah call $=$ trafik erlang $\mathrm{x} 1$ menit $/$ durasi MOC dan MTC.......

Sehingga dengan rata-rata durasi per call adalah 4 menit (MOC + MTC), maka jumlah call akan menjadi 904.000.000 erlang x 15 (60 menit / 4 menit $)=13.560 .000 .000$ call. Jika diasumsikan sesuai dengan formula Cisco [12] dimana 1 call $=11,2 \mathrm{Kbps}$ [12], maka total throughput VoLTE call akan menjadi 13,560,000,000 x 11,2 Kbps/call = 151.872.000.000 Kbps atau 151.872.000 Mbps. Throughput ini dikalkulasikan untuk mendapatkan payload per eNodeB seperti pada tabel 14.

\section{Tbl 14 Trafik Payload VoLTE per Spektrum Frekuensi}

Selanjutnya dengan cara perhitungan yang sama dengan konsumsi bandwidth pada layanan data LTE, dengan menggunakan perhitungan RB (Resource Block), maka diperoleh konsumsi bandwidth untuk layanan VoLTE seperti pada tabel 15 .

Tbl 15 Konsumsi Bandwidth Layanan VoLTE

\begin{tabular}{|c|c|c|c|c|c|c|c|c|c|c|}
\hline Tahun & Spektrum & $\begin{array}{c}\text { Payload per } \\
\text { BTS (Gbyte) }\end{array}$ & $\begin{array}{c}\text { Throughput } \\
\text { per BTS } \\
\text { (Mbps) }\end{array}$ & $\begin{array}{c}\text { Actual DL } \\
\text { Speed/ } \\
\text { Sector } \\
\text { (Mbps) }\end{array}$ & $\begin{array}{c}\text { Daya } \\
\text { Tampung/ } \\
\text { Cell }\end{array}$ & $\begin{array}{c}\text { DL Average } \\
\text { Throughput/Se } \\
\text { ctor (Mbps) }\end{array}$ & $\begin{array}{c}\text { DL Average } \\
\text { Throughput// } \\
\text { eNodeB } \\
\text { (Mbps) }\end{array}$ & $\begin{array}{c}\text { Symbol/ms } \\
\text { (spms) }\end{array}$ & $\begin{array}{c}\text { Resource } \\
\text { Blocks } \\
\text { (RB) }\end{array}$ & $\begin{array}{c}\text { BW } \\
\text { Consumption } \\
\text { (MHz) }\end{array}$ \\
\hline \multirow{2}{*}{$\begin{array}{c}\text { VoLTE } \\
\mathbf{2 0 1 4}\end{array}$} & $\mathbf{9 0 0 ~} \mathbf{~ M H z}$ & 11.13 & 25.33 & 1.689 & $70 \%$ & 2.412 & 7.24 & 905 & 5 & 0.969 \\
\cline { 2 - 12 } & $\mathbf{2 1 0 0} \mathbf{M H z}$ & 25.42 & 57.85 & 3.857 & $70 \%$ & 5.510 & 16.53 & 2066 & 12 & 2.214 \\
\hline
\end{tabular}

Sehingga hasil perhitungan konsumsi bandwidth dan biaya Frekuensi pada tiap spektrum seperti yang ditunjukkan pada tabel 16.

Tbl 16 Konsumsi Bandwidth, Trafik dan Biaya Frekuensi

\begin{tabular}{|c|c|c|c|c|c|c|c|c|c|c|c|c|c|c|c|c|}
\hline \multicolumn{17}{|c|}{ Frekuensi Telkomsel } \\
\hline Spektrum & \multicolumn{6}{|c|}{$900 \mathrm{MHz}$} & \multicolumn{5}{|c|}{$1800 \mathrm{MHz}$} & \multicolumn{5}{|c|}{$2100 \mathrm{MHz}$} \\
\hline Lebar Pita (Bandwidth, MHz) & \multicolumn{6}{|c|}{7.5} & \multicolumn{5}{|c|}{22.5} & \multicolumn{5}{|c|}{15} \\
\hline Biaya dasar per $1 \mathrm{MHz}$ (pp 76 tahun 2010) & \multirow{2}{*}{\multicolumn{6}{|c|}{$\begin{array}{r}6,202 \\
46,515\end{array}$}} & \multirow{2}{*}{\multicolumn{5}{|c|}{$\begin{array}{r}5,465 \\
122,963\end{array}$}} & \multicolumn{5}{|r|}{5,308} \\
\hline Biaya dasar per Spektrum & & & & & & & & & & & & \multirow{2}{*}{\multicolumn{5}{|c|}{$\begin{array}{r}79,620 \\
249,098\end{array}$}} \\
\hline \begin{tabular}{|l|} 
Total Baiaya Dasar Spektrum \\
\end{tabular} & & & & & & & & & & & & & & & & \\
\hline \begin{tabular}{|l} 
Tahun 2014 (Rp Milyar, annual report) \\
\end{tabular} & & & & & & & & & & & & \multicolumn{5}{|r|}{3,086} \\
\hline Biaya per Spektrum (Rp Milyar) & & & & & & 576.26 & & & & & $1,523.35$ & \multicolumn{5}{|r|}{986.39} \\
\hline \begin{tabular}{|l|} 
Biaya per $1 \mathrm{MHz}$ (Rp Milyar) \\
\end{tabular} & & & & & & 76.83 & & & & & 67.70 & \multicolumn{5}{|r|}{65.76} \\
\hline Layanan & Voice $2 \mathrm{G}$ & Data 2G & SMS & Data LTE & VoLTE & TOT 2G+3G & Voice 2G & \begin{tabular}{|l|l|} 
Data 2G \\
\end{tabular} & SMS & VoLTE & Total 2G+3G & Voice 3G & Data 3G & SMS & VoLTE & Total \\
\hline Occupancy Trafik (Juta Erlang/Tbyte/Juta SMS) & 150.67 & 9,537 & 3,500 & 1,014 & 10863 & NA & 452.38 & 28,050 & 10,500 & 32,588 & NA & 301.59 & 18,700 & 7,000 & 21,725 & NA \\
\hline Konsumsi Bandwidth (MHz) & 4.35 & 3.81 & 0.003 & 0.25 & 0.97 & 8.16 & 9.38 & 8.54 & 0.006 & 2.21 & 17.92 & 3.90 & 3.35 & 0.002 & 0.87 & 7.26 \\
\hline Konsumsi Bandwidth (\%) & $58 \%$ & $51 \%$ & $0.03 \%$ & $3 \%$ & $13 \%$ & $109 \%$ & $42 \%$ & $38 \%$ & $0.03 \%$ & $10 \%$ & $80 \%$ & $26 \%$ & $22 \%$ & $0.02 \%$ & $6 \%$ & $48 \%$ \\
\hline Biaya Konsumsi Bandwidth (Rp Milyar) & 334.21 & 292.88 & 0.200 & 19.35 & 74.46 & 627.29 & 634.73 & 577.97 & 0.403 & 149.88 & $1,213.10$ & 256.46 & 220.62 & 0.154 & 57.21 & 477.24 \\
\hline
\end{tabular}

Setelah melakukan regresi untuk tahun 2015, dengan hasil estimasi revenue, jumlah eNodeB, dan trafik playload pada tabel 8 , maka selanjutnya untuk menghitung probability digunakan analisis evaluasi proyek dengan variabel acak berlainan seperti pada tabel 17 . 
Tbl 17 Timeframe Capacity, Probability, dan Skenario Perubahan Tarif

\begin{tabular}{|c|c|c|c|c|c|}
\hline $\begin{array}{c}\text { Tingkat } \\
\text { Keyakinan }\end{array}$ & Tahun & $i$ & $\begin{array}{c}\text { Capacity } \\
(\%)\end{array}$ & Probability & $\begin{array}{c}\text { Perubahan } \\
\text { Tarif }\end{array}$ \\
\hline Optimistic & 2015 & 1 & 30 & 0.10 & $0 \%$ \\
\hline Optimistic & 2016 & 2 & 50 & 0.10 & $0 \%$ \\
\hline Most Likely & 2017 & 3 & 65 & 0.30 & $0 \%$ \\
\hline Most Likely & 2018 & 4 & 75 & 0.40 & $10 \%$ \\
\hline \multirow[t]{2}{*}{ Pessimistic } & 2019 & 5 & 90 & 0.10 & $-25 \%$ \\
\hline & \multicolumn{3}{|c|}{$\Sigma$} & 1.00 & \\
\hline
\end{tabular}

Tbl 18
Pada tabel 17, dilakukan penentuan timeframe untuk implementasi awal sesuai dengan kapasitas yang masih rendah terlebih dahulu yaitu sebesar $30 \%$ sehingga menimbulkan keyakinan optimistic, dibanding dengan jika kapasitas sudah mendekati $100 \%$ misalnya $90 \%$ dengan tingkat keyakinan pessimistic karena membutuhkan nilai investasi yang besar. Pemenuhan kapasitas jaringan misalnya dengan penambahan jumlah eNodeB, kapasitas perangkat core, dan perangkat lainnya, tentunya dimulai dengan tingkat keyakinan optimistic karena implementasi jumlah jaringan yang masih rendah.

\begin{tabular}{|c|c|c|c|c|c|c|c|c|c|c|c|c|c|}
\hline $\begin{array}{c}\text { Tingkat } \\
\text { Keyakinan }\end{array}$ & Tahun & $i$ & $\begin{array}{c}\text { Capacity } \\
(\%)\end{array}$ & $\begin{array}{c}\text { (A) } \\
\text { Probability } \\
p(X i)\end{array}$ & $\begin{array}{c}\text { (B) } \\
\text { Revenue } \\
X i\end{array}$ & $\begin{array}{c}\text { (A) } x(B) \\
\text { Expected LTE } \\
\text { Revenue (Rp) }\end{array}$ & $\begin{array}{c}\text { Revenue } \\
\text { (Tarif) } \\
\text { (Rp/MB) }\end{array}$ & $\begin{array}{c}\text { Traffic } \\
\text { (Payload } \\
\text {,TB) }\end{array}$ & $\begin{array}{c}\text { Payload } \\
\text { per eNB } \\
\text { (TB) }\end{array}$ & Jumlah eNB & $\begin{array}{c}\text { Jumlah } \\
\text { Spot } \\
\text { Area }\end{array}$ & $\begin{array}{c}\text { Strategi } \\
\text { Voice LTE }\end{array}$ & Revenue Max \\
\hline Optimistic & 2015 & 1 & 30 & 0.10 & $406,951,858,623$ & $40,695,185,862$ & 38 & 1,014 & \multirow{6}{*}{3} & 328 & 41 & CSFB & \multirow{5}{*}{$1,356,506,195,409$} \\
\hline Optimistic & 2016 & 2 & 50 & 0.10 & $678,253,097,705$ & $67,825,309,770$ & 38 & 1,690 & & 547 & 68 & SRVCC & \\
\hline Most Likely & 2017 & 3 & 65 & 0.30 & $881,729,027,016$ & $264,518,708,105$ & 38 & 6,590 & & 2,132 & 267 & $\mathrm{PS}-\mathrm{HO}$ & \\
\hline Most Likely & 2018 & 4 & 75 & 0.40 & $1,017,379,646,557$ & $406,951,858,623$ & 42 & 9,216 & & 2,982 & 373 & $\mathrm{PS}-\mathrm{HO}$ & \\
\hline \multirow[t]{2}{*}{ Pessimistic } & 2019 & 5 & 90 & 0.10 & $1,220,855,575,868$ & $122,085,557,587$ & 29 & 4,055 & & 1,312 & 164 & SRVCC & \\
\hline & \multicolumn{3}{|c|}{$\Sigma$} & 1.00 & Expected Revenue & $902,076,619,947$ & & 22,565 & & & & & \\
\hline
\end{tabular}

Sedangkan tingkat probability untuk optimistic sebesar 0,1 karena di awal proyek biasanya belum berpengalaman dan pessimistic juga sebesar 0,1 karena membutuhkan investasi yang lebih besar. Sedangkan most likely diasumsikan dengan probability 0,3 dan 0,4 .

Selanjutnya seperti pada tabel 18, dengan menggunakan variabel acak berlainan dengan estimasi revenue tahun 2015 sebesar Rp 40.695.185.862 dianggap sebagai expected revenue. Dengan menghitung nilai expected revenue pada tahun 2015 dengan tingkat probability 0,10 (optimistic) maka diperoleh nilai revenue sebesar $\mathrm{Rp}$ 40.695.185.862 / $0,10=\operatorname{Rp} 406.951 .858 .623$. Selanjutnya dapat dihitung nilai revenue maximum yaitu Rp 406.951.858.623 x 100\% / 30\% $=\operatorname{Rp} 1$ 1.356.506.195.409. Sehingga untuk selanjutnya dapat dihitung expected revenue pada tahun selanjutnya sampai tahun 2019, sebagai contoh perhitungan expected revenue pada tahun 2016 dengan cara menghitung terlebih dahulu revenue pada tahun 2016 menjadi 50\% (occupancy capacity) x Rp 1.356.506.195.409 = Rp 678.253.097.705. Selanjutnya expected revenue dapat dihitung dengan mengalikan nilai revenue dengan probability 0,10 (optimistic) menjadi $0,10 \mathrm{x}$ $\mathrm{Rp}$ 678.253.097.705 $=\mathrm{Rp}$ 67.825.309.770. Selanjutnya pola perhitungan yang sama dilakukan dari tahun 2017 sampai tahun 2019.

Tbl 19 Skenario Tarif, Trafik Payload, Jumlah eNodeB, Skenario Spot Area, dan Metode Prosedur Implementasi VoLTE

\begin{tabular}{|c|c|c|c|c|c|c|c|c|c|c|c|}
\hline $\begin{array}{c}\text { Tingkat } \\
\text { Keyakinan }\end{array}$ & Tahun & $i$ & $\begin{array}{c}\text { Capacity } \\
\text { (\%) }\end{array}$ & $\begin{array}{c}\text { (A) } \\
\text { Probability } \\
p(X i)\end{array}$ & $\begin{array}{c}(A) \times(B) \\
\text { Expected LTE } \\
\text { Revenue (Rp) }\end{array}$ & $\begin{array}{c}\text { Revenue } \\
\text { (Tarif) } \\
\text { (Rp/MB) }\end{array}$ & $\begin{array}{c}\text { Traffic } \\
\text { (Payload } \\
\text {, TB) }\end{array}$ & $\begin{array}{c}\text { Payload } \\
\text { per eNB } \\
\text { (TB) }\end{array}$ & Jumlah eNB & \begin{tabular}{|c} 
Jumlah \\
Spot \\
Area
\end{tabular} & $\begin{array}{l}\text { Metode } \\
\text { Voice LTE }\end{array}$ \\
\hline Optimistic & 2015 & 1 & 30 & 0.10 & $40,695,185,862$ & 38 & 1,014 & \multirow{6}{*}{3} & 328 & 41 & CSFB \\
\hline Optimistic & 2016 & 2 & 50 & 0.10 & $67,825,309,770$ & 38 & 1,690 & & 547 & 68 & SRVCC \\
\hline Most Likely & 2017 & 3 & 65 & 0.30 & $264,518,708,105$ & 38 & 6,590 & & 2,132 & 267 & PS-HO \\
\hline Most Likely & 2018 & 4 & 75 & 0.40 & $406,951,858,623$ & 42 & 9,216 & & 2,982 & 373 & PS-HO \\
\hline \multirow[t]{2}{*}{ Pessimistic } & 2019 & 5 & 90 & 0.10 & $122,085,557,587$ & 29 & 4,055 & & 1,312 & 164 & SRVCC \\
\hline & \multicolumn{3}{|c|}{$\Sigma$} & 1.00 & $902,076,619,947$ & & 22,565 & & & & \\
\hline
\end{tabular}

Metode Voice LTE (Jumlah Spot Area)

\begin{tabular}{ccccr}
\hline CSFB Max & SRVCC Max & SRVCC Min & \multicolumn{2}{c}{ PS-HO Min } \\
\hline $\mathbf{6 3}$ & 187 & 64 & 188 & \\
\hline Hasil perhitungan capex dan opex dari layanan LTE dan VoLTE & 2015 seperti pada tabel 20.Tbl 20 & Capex & dan
\end{tabular}

Opex LTE dan VoLTE 2015

\begin{tabular}{|c|c|c|c|c|c|c|r|r|}
\hline Periode & Tahun & $\begin{array}{c}\text { Expected } \\
\text { Revenue LTE }\end{array}$ & $\begin{array}{c}\text { Jumlah } \\
\text { eNodeB }\end{array}$ & $\begin{array}{c}\text { Penambahan } \\
\text { eNodeB }\end{array}$ & $\begin{array}{c}\text { Estimasi } \\
\text { CAPEX LTE } \\
\text { (Milyar Rp) }\end{array}$ & $\begin{array}{c}\text { Estimasi CAPEX } \\
\text { IMS \& Lainnya } \\
\text { (Milyar Rp) }\end{array}$ & $\begin{array}{c}\text { Estimasi } \\
\text { OPEX LTE } \\
\text { (Milyar Rp) }\end{array}$ & $\begin{array}{c}\text { Opex Spektrum } \\
\text { Asumsi 2014 } \\
\text { (Milyar Rp) }\end{array}$ \\
\hline 0 & 2014 & Optimistic & 110 & 110 & 47.29 & 0 & 31.55 & 32.01 \\
\hline 1 & 2015 & Optimistic & 328 & 218 & 73.90 & 0 & 31.40 & 384.15 \\
\hline 2 & 2016 & Optimistic & 547 & 219 & 74.13 & 81.00 & 31.40 & 384.15 \\
\hline 3 & 2017 & Most Likely & 2,132 & 1,585 & 537.43 & 162.00 & 94.20 & 384.15 \\
\hline 4 & 2018 & Most Likely & 2,982 & 850 & 288.09 & 0.00 & 94.20 & 384.15 \\
\hline 5 & 2019 & Pessimistic & 1,312 & $-1,670$ & 0.00 & 0.00 & 62.80 & 384.15 \\
\hline
\end{tabular}


Selanjutnya dilakukan perhitungan revenue VoLTE, contoh di spektrum $900 \mathrm{MHz}$ tahun 2016 berdasarkan volume based yang ditentukan dari trafik payload per eNodeB sebesar 4,160, $117 \mathrm{MB}$ dan jumlah eNodeB 544 (68x8) serta Tarif Rp 38 (rata-rata revenue/MB). Sedangkan revenue berdasarkan time based diperoleh dari throughput

Tbl 21 Revenue Layanan VoLTE Ber

\begin{tabular}{|c|c|r|r|r|r|r|r|}
\hline Tahun & $\begin{array}{c}\text { Jumlah } \\
\text { Spot } \\
\text { Area }\end{array}$ & $\begin{array}{c}\text { Expected } \\
\text { Revenue LTE } \\
\text { (Milyar Rp) }\end{array}$ & $\begin{array}{c}\text { Strategi } \\
\text { Voice LTE }\end{array}$ & $\begin{array}{c}\text { Tarif } \\
\text { Payload } \\
\text { (Rp/MB) }\end{array}$ & $\begin{array}{c}\text { Tarif Call } \\
\text { (Rp/Menit) }\end{array}$ & $\begin{array}{c}\text { Revenue VoLTE } \\
\text { (Volume Based, } \\
\text { Milyar Rp) }\end{array}$ & $\begin{array}{c}\text { Revenue VoLTE } \\
\text { (Time Based, } \\
\text { Milyar Rp) }\end{array}$ \\
\hline 2014 & 14 & 0.10 & CSFB & 38 & 1,080 & 0 & 0 \\
\hline 2015 & 41 & 40.70 & CSFB & 38 & 1,080 & 0 & 0 \\
\hline 2016 & 68 & 67.83 & SRVCC & 38 & 1,080 & 87.06 & 278.47 \\
\hline 2017 & 267 & 264.52 & PS-HO & 38 & 1,080 & 339.53 & $1,086.05$ \\
\hline 2018 & 373 & 406.95 & PS-HO & 42 & 1,080 & 522.35 & $1,518.94$ \\
\hline 2019 & 164 & 122.09 & SRVCC & 29 & 1,080 & 156.71 & 668.34 \\
\hline
\end{tabular}

Hasil perhitungan revenue layanan LTE yang dimulai dari bulan Desember 2014 dan layanan VoLTE dimulai dari tahun 2016 (cash in flow) serta biaya capex LTE dan IMS serta opex TSA, SPMS, dan transmisi backhaul (cash out flow) menjadi cash flow seperti pada tabel 22.

Tbl 22 Cash in dan Cash out Proyek Layanan VoLTE yang menghasilkan 235.834 call per eNodeB (dengan asumsi 1 call $=11,2 \mathrm{kbps}$ ) yang dikalikan dengan jumlah eNodeB dan tarif call 1.080 per menit (rata-rata MOC 2 menit), sehingga diperoleh nilai revenue untuk fitur layanan VoLTE berdasarkan volume based dan time based seperti pada tabel 21.

\begin{tabular}{cccc}
\hline Tahun & cash in & cash out & Profit \\
\hline Dec 2014 & 0.10 & 110.85 & $(110.75)$ \\
\hline $\mathbf{2 0 1 5}$ & 40.70 & 489.45 & $(448.76)$ \\
\hline $\mathbf{2 0 1 6}$ & 346.30 & 570.68 & $(224.38)$ \\
\hline $\mathbf{2 0 1 7}$ & $1,350.56$ & $1,177.78$ & 172.79 \\
\hline $\mathbf{2 0 1 8}$ & $1,925.90$ & 766.44 & $1,159.46$ \\
\hline $\mathbf{2 0 1 9}$ & 790.42 & 446.95 & 343.47 \\
\hline $\begin{array}{c}\text { Average } \\
\text { Annual }\end{array}$ & 890.77 & 690.26 & 200.52 \\
\hline
\end{tabular}

Tbl 23 Cash Flow, NPV, IRR, dan PBP

\begin{tabular}{|c|c|c|}
\hline Description (A1) & Value (B1) & Remark (C1) \\
\hline $\begin{array}{c}\text { Capital Investment - CAPEX (Rp } \\
\text { Milyar) Tahun } 2014\end{array}$ & 47.29 & Investasi Capex LTE : 110 eNB, Core \\
\hline Market Value (Rp) & 0 & \\
\hline Useful life (Tahun) & 5 & \\
\hline Study period, N (Tahun) & 6 & \\
\hline Total Revenue 2015 (Rp Milyar) & 40.70 & Hasil Regresi Linier Sederhana \\
\hline $\begin{array}{c}\text { Operational Expense }(\text { OPEX)(Rp } \\
\text { Milyar) Tahun } 2014\end{array}$ & 63.56 & $\begin{array}{l}\text { Including TSA, SPMS, backhaul lease line and } \\
\text { frequencies cost }\end{array}$ \\
\hline I (Interest Rate) & $12 \%$ & Tingkat suku bunga \\
\hline 2 & -224.38 & Cash flow 2016 (Rp Milyar) \\
\hline 3 & 172.79 & Cash flow 2017 (Rp Milyar) \\
\hline 4 & $1,159.46$ & Cash flow 2018 (Rp Milyar) \\
\hline 5 & 343.47 & Cash flow 2019 (Rp Milyar) \\
\hline Nett Present Value (NPV) & 364 & $=\mathrm{NPV}(\mathrm{B} 2, \mathrm{~B} 16: \mathrm{B} 20)+\mathrm{B} 15$ \\
\hline Annual Worth (AW) & 101 & $=\mathrm{PMT}(\mathrm{B} 2, \mathrm{~B} 5,-\mathrm{B} 22)$ \\
\hline Future Worth (FW) & 642 & $=\mathrm{FV}(\mathrm{B} 2, \mathrm{~B} 5,-\mathrm{B} 23)$ \\
\hline Internal Rate of Return (IRR) & $29.14 \%$ & $=\operatorname{IRR}(\mathrm{B} 15: \mathrm{B} 20, \mathrm{~B} 2)$ \\
\hline Payback Period $($ PBP) & 2.53 & \\
\hline
\end{tabular}


Untuk mengukur faktor yang paling mempengaruhi nilai NPV atau IRR untuk kelayakan bisnis LTE dan VoLTE yaitu dari lima faktor yang kemudian dibuat persen perubahan untuk faktor MARR (Minimum Attractive Rate of Return), market value, useful life, annual savings, dan cost. Dengan menggunakan grafik sensitivitas [13]

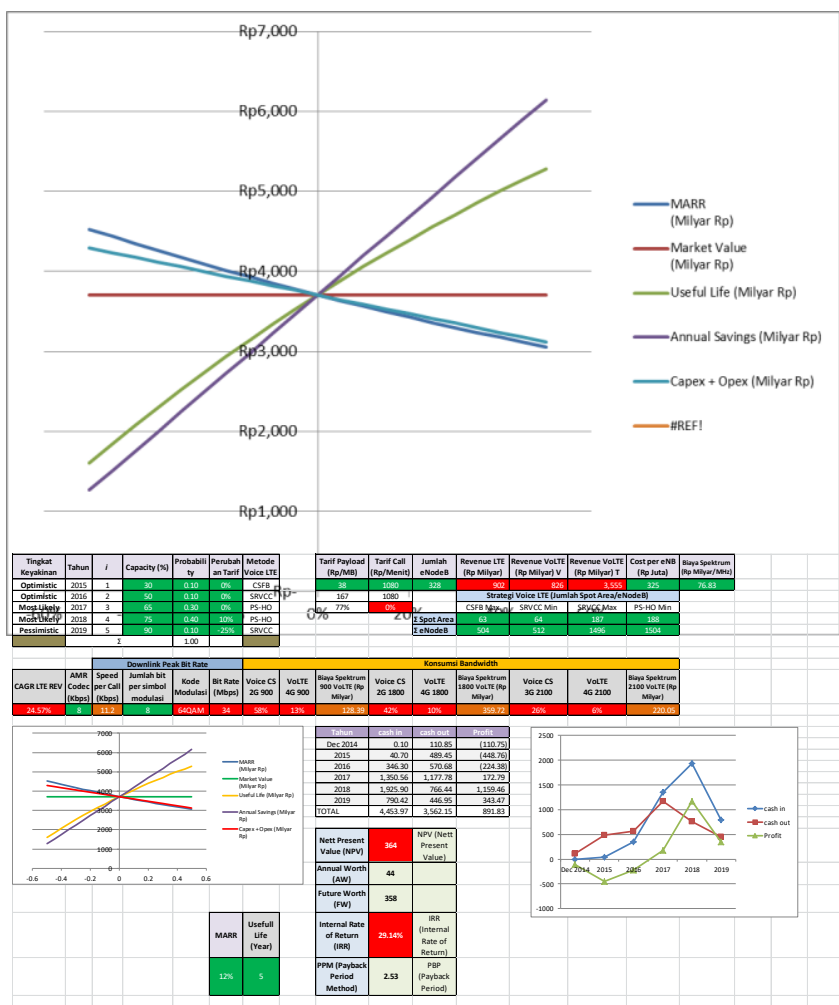

Gbr 5 Grafik Sensitivitas Dari 5 Faktor Yang Mempengaruhi NPV

Dengan menggunakan proses grafik dari excel scatter, maka diperoleh grafik seperti pada gambar 5. Dari lima faktor yang telah dianalisa, maka grafik sensitivitas (spider plot) tersebut mengindikasikan bahwa NPV (Nett Present Value) sangat sensitive terhadap perubahan nilai annual savings atau cash in, dimana annual savings terdiri dari revenue LTE dan revenue VoLTE yang juga sangat sensitif terhadap perubahan tarif. Sedangkan faktor yang paling tidak sensitive adalah market value, seperti yang diharapkan karena nilai uang yang kecil dan hanya muncul di akhir periode studi.

Sedangkan untuk mengukur nilai risiko maka digunakan simulasi Monte Carlo untuk nilai NPV tersebut diperlihatkan pada Gambar 6 dan untuk nilai IRR pada gambar 7.

Gbr 6 Simulasi Monte Carlo untuk Nett Present Value >0

Persyaratan kelayakan suatu investasi dapat ditinjau dari NPV. Dari Gambar 4.6, simulasi Monte Carlo dengan 10.000 iterasi didapatkan NPV > 0 memiliki probabilitas sebesar $100 \%$. Hasil ini memberikan tingkat keyakinan terhadap studi kelayakan proyek implementasi layanan VoLTE dan dengan hasil NPV = Rp 364 milyar, maka hipotesis studi kelayakan proyek implementasi layanan VoLTE terbukti. Sementara itu tingkat kelayakan investasi ditinjau dari sisi IRR, dimana batasan kelayakannya adalah IRR > MARR dimana MARR dipersyaratkan adalah lebih besar dari suku bunga pinjaman (10.41\%). Pada implementasi teknologi LTE dan layanan VoLTE ini MARR diasumsikan sebesar $12 \%$ dan kalkulasi dari tabel 22 dan tabel 23 menghasilkan IRR sebesar 29,14\% yang artinya IRR $>$ MARR.

Gbr $7 \quad$ Simulasi Monte Carlo untuk IRR > 12\%

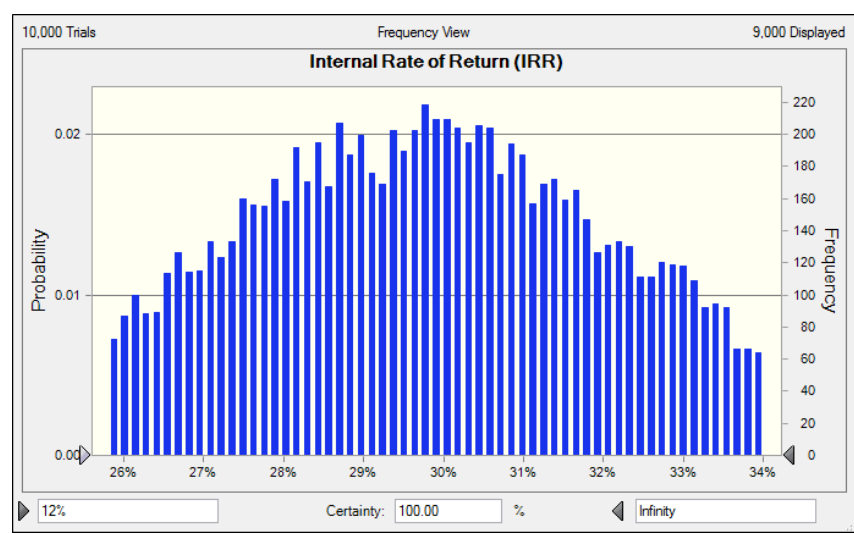

Dari simulasi Monte Carlo untuk nilai IRR pada gambar 4.7, terlihat dengan IRR > $12 \%$ dengan tingkat keyakinan $100 \%$, hal ini membuktikan studi implementasi layanan voice over LTE sangat layak.

\section{B. Validasi Model}

Dengan semua analisis yang telah dilakukan sebelumnya, maka dapat dilakukan validasi model terhadap kelayakan investasi fitur layanan VoLTE melalui dashboard model seperti pada gambar 8.

Gbr 8 Dashboard Model Untuk Impelementasi Fitur Layanan VoLTE

Melalui dashboard model pada gambar 8, dapat dilakukan simulasi perubahan variabel tarif, biaya, occupancy kapasitas, probability, jumlah spot area untuk metode implementasi VoLTE, perubahan tarif, dan lainnya. Pada dashboard model tersebut juga dapat dilakukan simulasi hasil yang diharapkan melalui analisis goal seek pada aplikasi excel untuk perubahan suatu parameter. Misalnya jika ingin melakukan setting terhadap NPV $=0$, kemudian ingin diketahui perubahan parameter tarif call yang kemudian berubah menjadi Rp 905/menit dari sebelumnya Rp 1080/menit, yang berarti untuk fitur VoLTE dapat dilakukan diskon tarif sampai $16 \%$ dari tarif normal. Demikian pula simulasi dapat dilakukan terhadap faktorfaktor dan variabel-variabel yang lain.

\section{KESIMPULAN}

Dengan model yang dibuat, perusahaan dapat



memaksimalkan kelayakan fitur layanan VoLTE dengan 
memilih waktu dan metode teknologi implementasi yang tepat, dengan kondisi sebagai berikut :

A. Fitur layanan VoLTE dapat layak untuk diimplementasikan dengan mempertimbangkan :

1) Penggunaan AMR codec $(4.75$ - $12.2 \mathrm{kbps})$, teknik modulasi (64QAM, 16QAM, QPSK), pilihan metode teknologi (SRVCC atau PS handover).

2) Pertumbuhan eNodeB terkait dengan proyeksi trafik secara deterministik maupun forecast dari unit usaha.

B. Dengan skenario tarif berdasarkan waktu bicara (time based) saat ini, VoLTE layak diimplementasikan dengan nilai risiko sangat rendah (probability mendekati 99\%). Disamping itu dengan tingkat minimal kelayakan bisnis, dimana NPV $=0$, maka dapat dilakukan diskon tarif voice call sampai $16 \%$.

C. Risiko implementasi LTE dapat diturunkan melalui penghematan penggunaan spektrum dari VoLTE. Penghematan bandwidth spektrum oleh VoLTE sekitar 4x dari voice CS (tahun 2014 biaya spektrum 20\% dari opex O\&M, padahal opex O\&M merupakan kontribusi terbesar sekitar 37\% dari total opex di Telkomsel).

\section{UCAPAN TERIMA KASIH}

Jika ada, ucapan terima kasih ini ditujukan kepada institusi resmi atau perorangan yang telah memberikan kontribusi penting dalam penelitian (misal penyandang dana, ahli, dll). Dalam bagian ini dilengkapi dengan nomor surat kontrak penelitian atau kerjasama.

\section{REFERENSI}

[1] Sullivan, N. Mishra, and Frost, "VoLTE finds significant traction in Asia," 2014.

[2] "www.telecoms.com (Feb 2014), SK Telecom to expand LTE-A network with 1.8 LTE-A network with $1.8 \mathrm{GHz}$ spectrum."

[3] M. Ulfah, "Peningkatan Area Jangkuan Jaringan 4G Lte (Studi Kasus Kecamatan Samarinda Ulu), J J. ECOTIPE, vol. 5, no. 1, pp. 33-38, 2018, doi: 10.33019/ecotipe.v5i1.32.

[4] T. Parker, "MetroPCS will launch VoLTE in $2 \mathrm{H}$ 2012.," 2012, [Online]. Available: www.fiercewireless.com.

[5] Ericsson, "Telkomsel LTE RFI, LTE Core Network Overview," 2014.

[6] I. Gemiharto, "Teknologi 4G-Lte Dan Tantangan Konvergensi Media Di Indonesia," J. Kaji. Komun., vol. 3, no. 2, pp. 212-220, 2015, doi: 10.24198/jkk.vol3n2.10.

[7] I. D. G. Paramartha Warsika, N. M. A. E. Dewi Wirastuti, and P. K. Sudiarta, "Analisa Throughput Jaringan 4G Lte Dan Hasil Drive Test Pada Cluster Renon," J. SPEKTRUM, vol. 6, no. 1, p. 74, 2019, doi: 10.24843/spektrum.2019.v06.i01.p11.

[8] R. Ishak, "Sistem Pendukung Keputusan Pemilihan Penyuluh Lapangan Keluarga," J. Ilm. Ilk., vol. 8, no. 3, pp. 160-166, 2016.

[9] Telkomsel, "Traffic Engineering Telkomsel, Data Trafik dan Revenue Telkomsel," 2015.

[10] A. Report, "Telkomsel (2003 - 2014)," 2019. [Online]. Available: https://www.rtda.gov.rw/fileadmin/templates/public
ations/RWANDA_Annual_Report_20182019_SHARING.pdf,.

[11] M. Wildan, "Tesis Implementasi LTE, Program Studi Pasca Sarjana Manajemen,” 2015.

[12] Cisco,

"http://www.cisco.com/c/en/us/support/docs/voice/ voice-quality/7934-bwidth-consume.html, VoIP Per Call Bandwidth." .

[13] A. Fauzani, “Analisis Sensitivitas Biaya Investasi Ditinjau Terhadap Faktor Ketidakpastian Dalam Pembangunan Prasarana Terminal Bandar Udara ( Proyek Pembangunan Prasarana Terminal Bandar Udara Syamsudin Noor Banjarmasin )," J. Teknol. Berkelanjutan, vol. 6, no. 1, pp. 57-66, 2017.

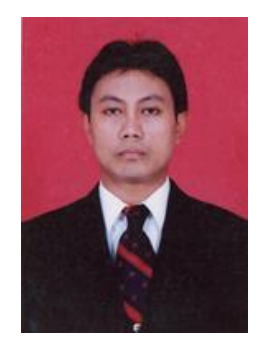

\section{BIOGRAFI PENULIS}

Enov Tikupasang, Lahir di Makassar, 6 November 1969. Bekerja sebagi tenaga pengajar di Program Studi Teknik Elektro Universitas Siliwangi dengan bidang konsentrasi ilmu manajemen telekomunikasi.

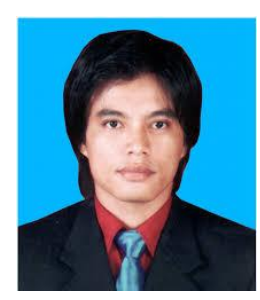

Nurul Hiron, Lahir di Balikpapan, 19Agustus 1975. Bekerja sebagai tenaga pengajar di Program Studi Teknik Elektro Universitas Siliwangi dengan bidang konsentrasi ilmu manajemen energi.

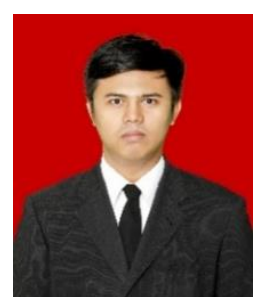

Imam Taufiqurrahman, lahir di Bandung pada tanggal 12 juni 1990, saai ini bertugas sebagai staf pengajar di Jurusan Teknik Elektro,Universitas SIliwangi, bidang penelitian yang ditekuni saat ini adalah Otomasi, Robotika dan Sistem Cerdas. 